\title{
ANALISIS PENDAPATAN USAHATANI PADI SAWAH BERDASARKAN SISTEM BAGI HASIL DI DESA WOLAANG KECAMATAN LANGOWAN TIMUR KABUPATEN MINAHASA
}

\author{
Anatasya Angelina Lelet \\ Yolanda Pinky Ivanna Rori \\ Joachim Noch Karel Dumais
}

Naskah diterima melalui Website Jurnal Ilmiah agrisosioekonomi@unsrat.ac.id Disetujui diterbitkan

Sabtu, 20 April 2019

: Kamis, 25 April 2019

\begin{abstract}
The objective of this research is to analyze the income of rice farming based on the revenue sharing system in Wolaang Village, East Langowan sub-district, Minahasa Regency. This research was conducted for 3 month, starting from January to March 2019. The Samples of farmers is using simple random sampling method (simple random). Data collected in this study are primary data and secondary data. Primary data was obtained from direct interviews with 30 farmer. While secondary data obtained from BP3K East Langowan sub-district and BPS Minahasa Regency, books available at local bookstores and the internet such as google searching to access articles from various scientific journals and thesis from other universities related to the topic of this research, especially income analyze. The results showed that the income received by landowners was Rp.13,462,500 while the income received by smallholders was smaller than that of landowners, namely Rp.9,940,865. ${ }^{* j n k d+e p r m *}$
\end{abstract}

Keywords: income, profit sharing system, wetland rice, Wolaang Village, Minahasa Regency.

\begin{abstract}
ABSTRAK
Tujuan penelitian ini adalah untuk menganalisis pendapatan usahatani padi sawah berdasarkan sistem bagi hasil di Desa Wolaang Kecamatan Langowan Timur Kabupaten Minahasa. Penelitian ini dilaksanakan selama 3 bulan mulai dari bulan Januari sampai Maret 2019.Penentuan sampel petani menggunakan Simple Random Sampling (acak sederhana). Data yang dikumpulkan dalam penelitian ini adalah data primer dan data sekunder. Data primer diperoleh dari wawancara langsung kepada 30 petani penggarap. Sedangkan data sekunder diperoleh dari BP3K Kecamatan Langowan Timur, BPS Kabupaten Minahasa, buku-buku yang tersedia di toko buku lokal dan internet seperti pencarian google untuk mengakses artikel dari berbagai jurnal ilmiah dan skripsi dari perguruan tinggi lain yang berkaitan dengan penelitian ini terutama menyangkut analisis pendapatan usahatani. Hasil Penelitian menunjukkan bahwa pendapatan yang diterima petani pemilik lahan yaitu sebesar Rp.13.462.500 sedangkan pendapatan yang diterima petani penggarap lebih kecil dari petani pemilik lahan yaitu sebesar Rp.9.940.865. ${ }^{\text {jnkd }+ \text { eprm* }}$
\end{abstract}

Kata Kunci : pendapatan, sistem bagi hasil, padi sawah, Desa Wolaang, Kabupaten Minahasa. 


\section{PENDAHULUAN}

\section{Latar Belakang}

Sektor pertanian merupakan sektor andalan sebagai pendorong pembangunan perekonomian nasional. Sektor pertanian sangat berperan dalam penyerapan tenaga kerja dan sebagai sumber utama kehidupan dan pendapatan masyarakat petani. Pertanian merupakan salah satu sumber kehidupan dari masyarakat Indonesia, dengan lahan pertaniannya yang sangat luas dan masih belum tergarap sempurna memacu masyarakatnya untuk lebih dapat memanfaatkan sumber daya alam tersebut. (Suratiyah 2015)

Salah satu sub sektor pertanian yang memiliki peranan penting adalah sub sektor tanaman pangan. Tanaman pangan merupakan komoditi penting bagi masyarakat Indonesia, beberapa tanaman pangan dijadikan sebagai makanan pokok karena mengandung sumber energi yang dibutuhkan manusia. Padi merupakan bahan pangan terpenting karena merupakan sumber karbohidrat. Kebutuhan akan bahan pangan utama khususnya beras setiap tahunnya semakin meningkat sesuai dengan laju pertumbuhan penduduk.

Peningkatan produksi pertanian khususnya tanaman pangan merupakan salah satu upaya pemerintah dalam membangun pertanian menuju pertanian yang tangguh, hal ini dikarenakan sektor pertanian memegang peranan yang sangat penting sebagai sumber utama kehidupan dan pendapatan masyarakat petani. Kontribusi utama sektor pertanian terhadap pembangunan nasional telah berhasil secara nyata meningkatkan penyediaan bahan pangan khususnya beras, menciptakan kesempatan kerja, dan meningkatkan kesejahteraan masyarakat (Daniel, 2001)

Kecamatan Langowan Timur merupakan kecamatan penghasil padi sawah ke lima terbesar di Kabupaten Minahasa dengan luas panen sebesar 1.224 Ha. Desa Wolaang merupakan desa dengan jumlah luas tanam terbesar di Kecamatan Langowan Tmur yaitu sebesar $147 \mathrm{Ha}$ digunakan untuk lahan pertanian khususnya digunakan untuk kegiatan padi sawah. Produksi yang di hasilkan sebesar 882 ton. Dapat dilihat pada tabel 1 .

\begin{tabular}{|c|c|c|c|}
\hline No & Desa & $\begin{array}{c}\text { Luas Tanam } \\
(\mathrm{Ha})\end{array}$ & Produksi (ton) \\
\hline 1. & Teep & 72 & 468 \\
\hline 2. & Wolaang & 147 & 882 \\
\hline 3. & Waleure & 20 & 130 \\
\hline 4. & Amongena I & 120 & 780 \\
\hline 5. & Amongena II & 130 & 845 \\
\hline 6. & Amongena III & 80 & 480 \\
\hline 7. & Karondoran & 60 & 390 \\
\hline 8. & Sumarayar & - & - \\
\hline
\end{tabular}

Masyarakat Desa Wolaang sebagian besar bermata pencaharian sebagai petani dan merupakan petani penggarap. Jumlah petani penggarap di Desa Wolaang berjumlah 92 orang. Pengolahan lahan pertanian di Desa Wolaang sebagian besar tidak di kerjakan oleh pemilik lahan secara langsung, melainkan bekerjasama dengan petani penggarap. Menurut Rahardjo (2004), penyakapan atau sistem bagi hasil adalah suatu bentuk ikatan ekonomi-sosial, dalam mana si pemilik tanah menyerahkan tanahnya untuk di garap orang lain (petani penyakap) dengan persyaratan-persyaratan yang disetujui bersama. Dalam bagi hasil ini terlibat dua pihak, yaitu antara pemilik lahan dan petani penggarap. Pelaku pertanian yang umumnya terdiri dari petani penggarap, pemilik lahan, dan buruh tani bekerjasama dalam kesepakatan yang telah disepakati bersama. Kesepakatan yang di maksud ini adalah dengan menggunakan sistem bagi hasil antara petani penggarap dan pemilik lahan.

Dalam penelitian ini peneliti hanya memfokuskan pada petani penggarap, karena di Desa Wolaang tidak semua petani memiliki lahan pertanian milik sendiri. Sistem bagi hasil yang berlaku di Desa Wolaang yaitu petani penggarap mendapat $2 / 3$ dan pemilik lahan mendapat $1 / 3$. Sistem bagi hasil antara petani penggarap dengan pemilik lahan sudah lama berlangsung dan secara turun temurun.

\section{Rumusan Masalah Penelitian}

Berdasarkan latar belakang yang telah diuraikan maka yang menjadi rumusan masalah dalam penelitian ini adalah berapakah pendapatan petani padi sawah berdasarkan sistem bagi hasil di Desa Wolaang Kecamatan Langowan Timur Kabupaten Minahasa? 


\section{Tujuan Penelitian}

Berdasarkan rumusan masalah maka tujuan penelitian ini adalah untuk mengetahui pendapatan petani padi sawah berdasarkan sistem bagi hasil di Desa Wolaang Kecamatan Langowan Timur Kabupaten Minahasa.

\section{Manfaat Penelitian}

1. Bagi peneliti, untuk menambah pengetahuan dan wawasan mengenai pendapatan petani padi sawah dalam sistem bagi hasil.

2. Bagi pihak lain, sebagai bahan referensi untuk peneliti lainnya, terutama yang berkaitan dengan penelitian ini

\section{METODE PENELITIAN}

\section{Waktu dan Tempat Penelitian}

Penelitian ini telah dilakukan selama 3 (tiga) bulan mulai dari bulan Januari sampai bulan Maret mulai dari tahap persiapan, pengambilan data dan sampai pada penyusunan penelitian. Dengan lokasi penelitian di Desa Wolaang Kecamatan Langowan Timur Kabupaten Minahasa.

\section{Metode Pengumpulan Data}

Data yang di kumpulkan dalam penelitian ini berupa dapa primer dan data sekunder. Data primer diperoleh dengan cara observasi langsung ke lokasi penelitian dan wawancara langsung dengan petani dengan menggunakan daftar pertanyaan yang telah di susun. Sedangkan data sekunder diperoleh dari instansi terkait yang berhubungan dengan penelitian ini yaitu BP3K Kecamatan Langowan Timur dan BPS Kabupaten Minahasa.

\section{Metode Pengumpulan Sampel}

Populasi penelitian adalah petani padi sawah yang menjadi petani penggarap lahan sawah milik orang lain yang berada di Desa Wolaang. Berdasarkan data yang di peroleh jumlah petani penggarap padi sawah sebanyak 92 orang. Metode pengumpulan sampel yang digunakan dalam penelitian ini menggunakan Simple Random Sampling atau secara acak sederhana. Cara pengambilan sampel menggunakan rumus Slovin :

Dimana:

$$
\mathrm{n}=\frac{N}{1+N \cdot e^{2}}
$$

$\mathrm{n}=$ Besar Sampel

$\mathrm{N}=$ Besar Populasi

$1=$ Konstanta

$\mathrm{e}^{2}=$ Persentase kelonggaran akibat kesalahan pengambilan sampel yang ditolerir, dalam penelitian ini digunakan kesalahan pengambilan sampel sebesar $15 \%$.
Dengan tingkat presisi (15\%), dari jumlah petani yang ada peneliti mengunakan sampel yang bisa mewakili jumlah keseluruhan petani tersebut yaitu sebanyak 30 orang.

\section{Konsep Pengukuran Variabel}

Variabel-variabel yang di ukur dalam penelitian ini adalah :

1. Karakteristik Responden :
a. Umur
b. Tingkat Pendidikan (SD, SMP, SMA/SMK dan Perguruan Tinggi)
c. Lamanya berusahatani

2. Luas lahan

Ialah luas areal tanaman padi, di ukur dalam satuan $(\mathrm{Ha})$.

3. Produksi

Jumlah yang dihasilkan dalam satu kali musim tanam, di ukur dalam (Kg).

4. Biaya Produksi

a. Biaya tetap

i. Biaya Pajak (Rp/musim tanam)

ii. Penyusutan alat (Rp/musim tanam)

b. Biaya Variabel

i. Biaya Tenaga Kerja (Rp)

ii. Biaya Benih, yaitu banyaknya benih yang digunakan oleh petani dalam usahatani padi sawah $(\mathrm{Rp} / \mathrm{Kg})$

iii. Biaya Pupuk ( $\mathrm{Rp} / \mathrm{Kg})$

iv. Biaya Transportasi (Rp)

v. Biaya Total, biaya tetap ditambah biaya variabel dalam satu kali musim tanam.

5. Harga jual, yaitu harga yang berlaku di tingkat petani ( $\mathrm{Rp} / \mathrm{Kg})$.

6. Penerimaan adalah jumlah produksi dikalikan dengan harga jual (Rp)

7. Pendapatan adalah selisih antara total penerimaan dan total biaya ( $\mathrm{Rp})$

\section{Teknik Analisis Data}

Analisis yang digunakan dalam penelitian ini adalah analisis pendapatan usahatani yaitu dengan menghitung selisih penerimaan dengan biaya yang digunakan. Data yang dikumpulkan akan disajikan dalam bentuk variabel dan deskriptif.

a. Menurut Sukirno (2006) untuk menghitung biaya total menggunakan rumus :

$$
\mathbf{T C}=\mathbf{T F C}+\mathbf{T V C}
$$

Dimana :

$$
\begin{aligned}
& \mathrm{TC}=\text { Total Cost }(\text { Biaya Total }) \\
& \mathrm{TFC}=\text { Total Fixed Cost }(\text { Biaya Tetap Total }) \\
& \text { TVC }=\text { Total Variable Cost }(\text { Biaya Variabel Total })
\end{aligned}
$$


b. Menurut Boediono (2016) untuk mengetahui jumlah penerimaan yang di peroleh dapat diketahui menggunakan rumus :

$$
\mathbf{T R}=\mathbf{Q} \times \mathbf{P}_{\mathbf{Q}}
$$

Dimana :

$$
\begin{aligned}
& \text { TR = Total Revenue (Total } \\
& \text { Penerimaan) } \\
& Q=\text { Quantity (Jumlah Produksi) } \\
& \mathrm{P}=\text { Price (Harga Jual) }
\end{aligned}
$$

c. Menurut Suratiyah (2008) untuk menghitung pendapatan dapat dihitung menggunakan rumus :

$$
\mathbf{I}=\mathbf{T R}-\mathbf{T C}
$$

\section{Dimana :}

$$
\begin{array}{ll}
\mathrm{I} & =\text { Income }(\text { Pendapatan }) \\
\mathrm{TR} & =\text { Total Revenue }(\text { Total Penerimaan }) \\
\mathrm{TC} & =\text { Total Cost }(\text { Total Biaya })
\end{array}
$$

\section{HASIL DAN PEMBAHASAN}

\section{Deskripsi Daerah Penelitian}

\section{Letak Dan Luas Wilayah}

Desa Wolaang merupakan desa yang terletak di wilayah Kecamatan Langowan Timur, Kabupaten Minahasa, dengan luas wilayah sebesar $216 \mathrm{Ha}$, yang mempunyai batasbatas wilayah sebagai berikut:

Sebelah Utara : Desa Amongena 2

Sebelah Barat : Desa Tonelet

Sebelah Selatan: Desa Winebetan

Sebelah Timur : Desa Teep

\section{Penduduk}

Penduduk Desa Wolaang Kecamatan Langowan Timur Kabupaten Minahasa berjumlah 2.474 jiwa, terdiri atas 1248 jiwa lakilaki dan 1226 jiwa perempuan dengan jumlah kepala keluarga sebanyak 816.

\section{a. Jumlah Penduduk Berdasarkan Jenis Pekerjaan}

Masyarakat desa Wolaang memiliki mata pencaharian yang relatife beragam. Sebagian besar masyarakat di Desa Wolaang sudah bekerja dengan berbagai profesi pekerjaan yang berbeda-beda. Jumlah penduduk berdasarkan jenis pekerjaan dapat dilihat pada Tabel 2.

\begin{tabular}{ccc} 
Tabel 2. Jumlah Penduduk Berdasarkan Jenis Pekerjaan \\
\hline Jenis Pekerjaan & Jumlah & $\begin{array}{c}\text { Persentase } \\
(\mathbf{\%})\end{array}$ \\
\hline Petani & 147 & 42 \\
Peternak & 29 & 8 \\
Pedagang & 45 & 13 \\
Tukang Kayu & 3 & 1 \\
Tukang Batu & 27 & 8 \\
Penjahit & 9 & 3 \\
PNS & 37 & 11 \\
Pensiunan & 31 & 9 \\
TNI/Polri & 4 & 1 \\
Pengrajin & 8 & 2 \\
Industri Kecil & 8 & 2 \\
\hline Total & $\mathbf{7 4 5}$ & $\mathbf{1 0 0}$ \\
\hline
\end{tabular}

Sumber: Diolah Dari Data Primer, 2019

Berdasarkan tabel 2 dapat dilihat bahwa jenis pekerjaan masyarakat desa Wolaang terbanyak pada sektor pertanian, dengan jumlah petani sebanyak 147 orang dengan perentase sebesar $42 \%$. Sehingga dapat dikatakan sektor pertanian merupakan sumber penghasilan utama bagi masyarakat di Desa Wolaang.

\section{b. Jumlah Penduduk Berdasarkan Jenis Usahatani}

Selain berusahatani padi sawah jenis usahatani yang lain yang dijalankan masyarakat desa Wolaang yaitu tomat, daun bawang dan ketimun. Jumlah Penduduk Berdasarkan Jenis Usahatani di Desa Wolaang dapat dilihat pada Tabel 3.

\begin{tabular}{ccc}
\multicolumn{3}{c}{ Tabel 3. Jumlah Penduduk Berdasarkan Jenis Usahatani } \\
\hline $\begin{array}{c}\text { Jenis } \\
\text { Usahatani }\end{array}$ & Jumlah & $\begin{array}{c}\text { Persentase } \\
\text { (orang) }\end{array}$ \\
\hline Padi Sawah & 92 & 87 \\
Tomat & 7 & 6 \\
Daun Bawang & 4 & 4 \\
Ketimun & 3 & 3 \\
\hline Total & $\mathbf{1 0 6}$ & $\mathbf{1 0 0}$
\end{tabular}

Sumber: Diolah Dari Data Primer, 2019

Berdasarkan tabel 3 dapat dilihat bahwa jenis usahatani yang dijalankan masyarakat desa Wolaang, terbanyak pada usahatani padi sawah dengan jumlah 92 orang dengan persentase sebesar 87.

\section{c. Jumlah Penduduk Berdasarkan Status Petani} Status petani di Desa Wolang terbagi menjadi 2 yaitu pemilik lahan dan petani penggarap. Jumlah penduduk berdasarkan status petani dapat dilihat pada Tabel 4.

\begin{tabular}{ccc} 
Tabel 4. Jumlah Penduduk Berdasarkan Status Petani \\
\hline $\begin{array}{c}\text { Jenis } \\
\text { Usahatani }\end{array}$ & $\begin{array}{c}\text { Jumlah } \\
\text { (orang) }\end{array}$ & $\begin{array}{c}\text { Persentase } \\
(\%)\end{array}$ \\
\hline Pemilik Lahan & 20 & 18 \\
Petani Penggarap & 92 & 82 \\
\hline Total & $\mathbf{1 1 2}$ & $\mathbf{1 0 0}$
\end{tabular}

Sumber: Diolah Dari Data Primer, 2019 
Berdasarkan tabel 4 dapat dilihat bahwa status petani di desa Wolaang terbanyak pada petani penggarap, dengan jumlah petani sebanyak 92 orang dengan peresentase sebesar $82 \%$. Hal ini terlihat jelas bahwa sebagian besar masyarakat desa Wolaang merupakan petani penggarap.

\section{Karakteristik Responden}

\section{Umur}

Umur akan berpengaruh terhadap kemampuan fisik dalam melakukan kegiatan usahatani. Jumlah responden menurut umur di Desa Wolaang dapat di lihat pada Tabel 5.

\begin{tabular}{ccc} 
Tabel 5. Jumlah Responden Menurut Umur & \\
\hline $\begin{array}{c}\text { Umur } \\
\text { (Tahun) }\end{array}$ & $\begin{array}{c}\text { Jumlah } \\
\text { Responden } \\
\text { (Orang) }\end{array}$ & $\begin{array}{c}\text { Persentase } \\
(\%)\end{array}$ \\
\hline$<30$ & 4 & 13 \\
$31-40$ & 3 & 10 \\
$41-50$ & 10 & 34 \\
$51-60$ & 7 & 23 \\
$>61$ & 6 & 20 \\
\hline Total & $\mathbf{3 0}$ & $\mathbf{1 0 0}$
\end{tabular}

Sumber: Diolah Dari Data Primer, 2019

Berdasarkan tabel 5 dapat dilihat bahwa jumlah responden terbesar yaitu sebesar 34\% berada pada kisaran umur 41-50 tahun dan diikuti oleh kisaran umur 51-60 tahun dengan persentase sebesar 23\%. Umur responden masih tergolong produktif, dimana petani cukup kuat dan giat dalam melakukan kegiatan usahataninya, dapat dilihat dari produktivitas yang dihasilkan yang cukup optimal.

\section{Tingkat Pendidikan}

Pendidikan merupakan salah satu faktor penting dalam usaha peningkatan kualitas sumber daya manusia, serta peningkatan kualitas intelektual dan wawasan seseorang. Jumlah responden menurut tingkat pendidikan dapat dilihat pada Tabel 6 .

\begin{tabular}{ccc} 
Tabel 6. Jumlah Responden Menurut Tingkat Pendidikan \\
\hline $\begin{array}{c}\text { Tingkat } \\
\text { Pendidikan }\end{array}$ & $\begin{array}{c}\text { Jumlah } \\
\text { Responden } \\
\text { (Orang) }\end{array}$ & $\begin{array}{c}\text { Persentase } \\
(\%)\end{array}$ \\
\hline SD & 13 & 44 \\
SMP & 9 & 30 \\
SMA & 7 & 23 \\
S1 & 1 & 3 \\
\hline Total & $\mathbf{3 0}$ & $\mathbf{1 0 0}$ \\
\hline
\end{tabular}

Sumber: Diolah Dari Data Primer, 2019
Berdasarkan tabel 6 jumlah responden terbesar berada pada tingkat SD dengan jumlah responden sebanyak 13 orang dengan persentase $44 \%$ dan tingkat terendah pada tingkat S1 dengan jumlah responden 1 orang dengan persentase sebesar $3 \%$. Maka dapat dikatakan bahwa tingkat pendidikan petani responden padi sawah di Desa Wolaang masih berpendidikan rendah sehingga perlu ada penyuluhan pertanian dalam membimbing petani agar dapat merubah pola pikir sehingga dapat menerima inovasi baru.

\section{Lamanya Berusahatani}

Cara berusahatani seseorang sebagian besar dipengaruhi dari lamanya berusahatani. Petani yang memiliki pengalaman berusahatani lebih lama akan memiliki banyak pengetahuan dan wawasan terhadap usahatani yang dikelolahnya. Jumlah responden menurut lamanya berusahatani, dapat dilihat pada Tabel 7.

\begin{tabular}{ccc}
\multicolumn{3}{c}{ Tabel 7. Jumlah Responden Menurut Lamanya Berusaha Tani } \\
\hline $\begin{array}{c}\text { Lamanya } \\
\begin{array}{c}\text { Berusaha Tani } \\
\text { (Tahun) }\end{array}\end{array}$ & $\begin{array}{c}\text { Jumlah } \\
\text { Responden } \\
\text { (Orang) }\end{array}$ & $\begin{array}{c}\text { Persentase } \\
(\%)\end{array}$ \\
\hline$<10$ & 5 & 17 \\
$11-30$ & 18 & 60 \\
$>31$ & 7 & 23 \\
\hline Total & $\mathbf{3 0}$ & $\mathbf{1 0 0}$
\end{tabular}

Berdasarkan tabel 7 dapat dilihat bahwa lamanya berusahatani petani responden terbesar yaitu sebesar $60 \%$ pada lamanya berusahatani 11-30 tahun dengan jumlah responden sebanyak 18 orang. Petani responden padi sawah di Desa Wolaang memiliki pengalaman yang cukup lama dan baik dalam mengelola usahataninya dan juga didasarkan pada kemampuan dan keterampilan yang dimiliki sehingga dapat memberikan kemajuan untuk menghasilkan produksi yang lebih maksimal.

\section{Luas Lahan}

Lahan adalah salah satu faktor produksiyang mempunyai peranan penting dalam pertanian. Luas lahan yang dimiliki petani responden di Desa Wolaang sangat bervariasi dapat dilihat pada Tabel 8 .

Tabel 8. Jumlah Responden Menurut Luas Lahan yang

\begin{tabular}{ccc}
\multicolumn{2}{c}{ Diusahakan } & \\
\hline $\begin{array}{c}\text { Luas Lahan } \\
(\mathrm{Ha})\end{array}$ & $\begin{array}{c}\text { Jumlah } \\
\text { Responden } \\
\text { (Orang) }\end{array}$ & $\begin{array}{c}\text { Persentase } \\
(\%)\end{array}$ \\
\hline$<1$ & 8 & 27 \\
$1-2$ & 20 & 67 \\
$>2$ & 2 & 6 \\
\hline Total & $\mathbf{3 0}$ & $\mathbf{1 0 0}$ \\
\hline
\end{tabular}

Sumber: Diolah Dari Data Primer, 2019 
Tabel 8 menunjukkan luas lahan terbesar petani responden pada luas lahan $1-2 \mathrm{Ha}$ dengan rata-rata luas lahan $1.075 \mathrm{Ha}$ dengan jumlah responden sebanyak 20 orang. Dengan demikian variabel luas lahan berpengaruh terhadap produksi padi sawah di Desa Wolaang, yang berarti semakin besar luas lahan semakin besar pula produksi padi sawah yang diperoleh.

\section{Harga Jual}

Jenis beras yang di jual petani responden di Desa Wolaang yaitu jenis beras superwin, dengan harga jual yaitu Rp.10.000/kg dalam bentuk beras.

\section{Biaya Sarana Produksi}

Biaya sarana produksi adalah biaya yang di keluarkan untuk pembelian saprodi dalam usahatani. Sarana produksi yang digunakan petani responden di Desa Wolaang meliputi, benih, pupuk, pestisida dan obat-obatan. Rata-rata biaya saprodi yang dikeluarkan petani responden di Desa Wolaang dapat dilihat pada Tabel 9.

\begin{tabular}{|c|c|c|c|}
\hline $\begin{array}{c}\text { Sarana } \\
\text { Produksi }\end{array}$ & $\begin{array}{l}\text { Pemakaian } \\
\text { (Satuan) }\end{array}$ & $\begin{array}{c}\text { Harga } \\
(\mathrm{Rp})\end{array}$ & $\begin{array}{c}\text { Rata-rata } \\
\text { Biaya } \\
\text { (Rp/Ha) }\end{array}$ \\
\hline Benih & $85 \mathrm{Kg}$ & 4.471 & 380.035 \\
\hline Pupuk Urea & 6 unit & 90.000 & 540.000 \\
\hline $\begin{array}{l}\text { Pupuk SP } \\
36\end{array}$ & 6 unit & 125.000 & 750.000 \\
\hline $\begin{array}{l}\text { Pupuk } \\
\text { Phonska }\end{array}$ & 4 unit & 125.000 & 500.000 \\
\hline Pestisida & 1 unit & 300.000 & 300.000 \\
\hline Obat-obatan & 1 unit & 200.000 & 200.000 \\
\hline Total & & 1.220 .035 & 2.670 .035 \\
\hline
\end{tabular}

Tabel 9 menunjukkan bahwa rata-rata biaya sarana produksi usahatani padi sawah per hektar sebesar Rp. 2.670.035. Hasil penelitian mendapati bahwa biaya pupuk merupakan kontribusi terbesar dalam biaya saprodi.

\section{Biaya Penyusutan Alat}

Peralatan merupakan sarana penunjang dalam suatu kegiatan usahatani yang perluh dimiliki oleh petani. Peralatan yang digunakan oleh petani responden di Desa Wolaang yaitu cangkul, parang, mesin pemotong rumput dan hand sprayer. Rata-rata biaya penyusutan alat petani responden di Desa Wolaang dapat dilihat pada Tabel 10.
Tabel 10. Rata-rata Biaya Penyusutan alat Per Musim Tanam

\begin{tabular}{lccccc}
\hline Uraian & $\begin{array}{c}\text { Jumlah } \\
\text { (Unit) }\end{array}$ & $\begin{array}{c}\text { Nilai } \\
\text { Awal }\end{array}$ & $\begin{array}{c}\text { Nilai } \\
\text { Akhir }\end{array}$ & $\begin{array}{c}\text { Umur } \\
\text { Ekonomi } \\
\text { (Rp/musim } \\
\text { tanam) }\end{array}$ & $\begin{array}{c}\text { Biaya } \\
\text { Penyusutan } \\
\text { (Rp/musim } \\
\text { tanam) }\end{array}$ \\
\hline $\begin{array}{l}\text { Penyustan } \\
\text { alat } \\
\text { - Cangkul }\end{array}$ & 2 & 200.000 & 8.000 & 10 & 19.200 \\
-Parang & 2 & & 8.000 & 10 & 15.200 \\
-Mesin & 1 & 160.000 & 20.000 & 10 & 108.000 \\
$\begin{array}{l}\text { Pemotong } \\
\text { Rumput } \\
\text {-Hand }\end{array}$ & 1 & 1.100 .000 & & & 34.200 \\
Sprayer & & 8.000 & 10 & \\
& & 350.000 & & & \\
\hline \multicolumn{7}{r}{ Total } \\
\hline Sumber: Diolah Dari Data Primer, 2019
\end{tabular}

Tabel 10 menunjukkan bahwa nilai penyusutan alat per musim tanam usahatani padi sawah dengan nilai penyusutan terbesar pada mesin pemotong rumput sebesar Rp. 108.000 per musim tanam, dan diikuti hand sprayer dengan nilai penyusutan sebesar Rp.34.200 per musim tanam

\section{Biaya Tenaga Kerja}

Biaya tenaga kerja merupakan hasil perkalian hari orang kerja, dengan upah tenaga kerja. Biaya tenaga kerja petani responden di Desa Wolaang dimulai dari pengolahan lahan, penanaman, pemupukan, penyemprotan, dan sampai pada panen. Tenaga kerja terdiri atas tenaga kerja pria dan tenaga kerja wanita, yang berasal dari luar keluarga. Rata-rata biaya tenaga kerja per musim tanam usahatani padi sawah di Desa Wolaang dapat dilihat pada Tabel 11.

\section{Tabel ll. Rata-Rata Biaya Tenaga Kerja Per Musim Tanam}

\begin{tabular}{|c|c|c|c|c|c|}
\hline \multirow[b]{2}{*}{ Uraian } & Jumlah TK & \multirow[b]{2}{*}{$\begin{array}{c}\text { Jumlah Hari } \\
\text { Kerja }\end{array}$} & \multirow{2}{*}{$\begin{array}{c}\text { Jumla } \\
\mathrm{h} \\
\mathrm{HOK}\end{array}$} & \multirow{2}{*}{$\begin{array}{c}\text { Biaya } \\
(\mathrm{Rp} / \\
\mathrm{HOK})\end{array}$} & \multirow{2}{*}{$\begin{array}{c}\text { Rata-rata } \\
\text { Biaya } \\
\text { (Rp) }\end{array}$} \\
\hline & $\begin{array}{l}\text { TKDK } \\
\text { TKLK }\end{array}$ & & & & \\
\hline \multirow[t]{2}{*}{ Penanaman } & 12 & 3 & 6 & 150.000 & 900.000 \\
\hline & 1 & 3 & 3 & 125.000 & 375.000 \\
\hline Pemupukan & 12 & 3 & 6 & 150.000 & 900.000 \\
\hline Penyemprotan & $=1$ & 3 & 3 & 150.000 & 450.000 \\
\hline Panen & & & & & 7.500 .000 \\
\hline$\cdot \mathrm{TK}$ & & & & & \\
\hline - Rontok & & & & & \\
\hline $\begin{array}{l}\text { - Transp } \\
\text { ort }\end{array}$ & & & & & \\
\hline Traktor & & & & & 1.800 .000 \\
\hline Giling & & & & & 2.250 .000 \\
\hline Total & & & & & 14.175 .000 \\
\hline
\end{tabular}


Tabel 11 menunjukkan bahwa upah tenaga kerja yang berlaku di desa Wolaang adalah Rp.150.000/hari untuk pria dan Rp125.000/hari untuk wanita. Untuk tenaga kerja wanita hanya pada kegiatan penanaman. Pada panen biaya yang dikeluarkan sebesar Rp. 7.500.000 dengan sistem borong. Pada traktor dan giling merupakan biaya penyewaan alat.

\section{Biaya Tetap Usahatani}

$\begin{array}{cccc} & \text { Biaya tetap merupakan biaya yang } \\ \text { secara } & \text { total } & \text { tidak } & \text { mengalami }\end{array}$ perubahan,walaupun ada perubahan volume produksi atau penjualan dalam batas waktu tertentu. Yang termasuk biaya tetap, seperti penyusutan alat dan pajak. Rata-rata biaya tetap usahatani padi sawah di Desa Wolaang dapat dilihat pada Tabel 12 .

Tabel 12. Rata-rata Biaya Tetap Per Musim Tanam

\begin{tabular}{cc}
\hline Uraian & $\begin{array}{c}\text { Rata-rata Biaya Tetap } \\
(\mathrm{Rp} / \mathrm{thn})\end{array}$ \\
\hline Penyusutan alat & 176.600 \\
Pajak & 37.500 \\
\hline Total & $\mathbf{2 1 4 . 1 0 0}$ \\
\hline Sumber: Diolah Dari Data Primer, 2019
\end{tabular}

Tabel 12 menunjukkan bahwa rata-rata biaya tetap usahatani padi sawah terbesar pada biaya penyusutan alat sebesar Rp. 176.600 dan untuk biaya pajak Rp.37.500 ditanggung oleh pemilik lahan.

\section{Biaya Variabel Usahatani Padi Sawah}

Biaya Variabel merupakan biaya yang secara total berubah-ubah sesuai dengan perubahan volume produksi atau penjualan. Yang termasuk biaya variabel dalam usahatani padi sawah di Desa Wolaang yaitu biaya benih, pupuk, obat-obatan, pestisida tenaga kerja dan penyewaan alat. Ratarata biaya variabel usahatani padi sawah Di Desa Wolaang dapat dilihat pada Tabel 13.

Tabel 13. Rata-Rata Biaya Variabel Per Musim Tanam

\begin{tabular}{cc}
\hline Uraian & $\begin{array}{c}\text { Rata-rata Biaya Variabel } \\
(\mathrm{Rp})\end{array}$ \\
\hline Pembelian Saprodi & 2.670 .035 \\
Biaya Tenaga Kerja & 14.175 .000 \\
\hline Total & $\mathbf{1 6 . 8 4 5 . 0 3 5}$ \\
\hline Sumber: Diolah Dari Data Primer, 2019
\end{tabular}

Tabel 13 menunjukkan rata-rata biaya variabel usahatani padi sawah terbesar yaitu pada biaya tenaga kerja dengan biaya sebesar Rp.16.845.035.

\section{Biaya Produksi Usahatani Padi Sawah}

Biaya produksi merupakan keseluruhan biaya yang di keluarkan petani dalam usahatani baik biaya tetap berupa penyusutan alat dan pajak dan biaya variabel yang terdiri dari biaya benih, pupuk, pestisida, obat-obatan, biaya tenaga kerja dan penyewaan alat. Biaya produksi usahatani padi sawah di Desa Wolaang dapat dilihat pada Tabel 14

Tabel 14. Rata-rata Penggunaan Biaya Produksi Per Musim Tanam

\begin{tabular}{cc} 
Tanam & \\
\hline Penggunaan Biaya Produksi & $\begin{array}{c}\text { Rata-rata Biaya } \\
(\mathrm{Rp})\end{array}$ \\
\hline Biaya Tetap & 214.100 \\
Biaya Variabel & 16.845 .035 \\
\hline Total & $\mathbf{1 7 . 0 5 9 . 1 3 5}$ \\
\hline
\end{tabular}

Sumber: Diolah Dari Data Primer, 2019

Tabel 14 menunjukkan bahwa rata-rata penggunaan biaya produksi usahatani padi sawah terbesar pada biaya variabel dengan biaya sebesar Rp. 17.059.135.

\section{Penerimaan Usahatani}

Penerimaan Usahatani merupakan perkalian antara biaya produksi yang diperoleh dengan harga jual. Penerimaan usahatani padi sawah di Desa Wolaang dapat dilihat pada Tabel 15.

Tabel 15. Penerimaan Usahatani Padi Sawah Per Musim Tanam

\begin{tabular}{ccc}
\hline $\begin{array}{c}\text { Jumlah Produksi } \\
\text { Beras }(\mathrm{Kg})\end{array}$ & $\begin{array}{c}\text { Harga Jual } \\
(\mathrm{Rp} / \mathrm{Kg})\end{array}$ & $\begin{array}{c}\text { Total Penerimaan } \\
(\mathrm{Rp})\end{array}$ \\
\hline 4.050 & 10.000 & 40.500 .000 \\
\hline Sumber: Diolah Dari Data Primer, 2019 &
\end{tabular}

Tabel 15 menunjukkan bahwa jumlah produksi yang dihasilkan sebesar $4050 \mathrm{Kg}$ dalam bentuk beras dengan harga jual Rp.10.000/Kg maka total penerimaan yang diperoleh sebesar $\mathrm{Rp}$. 40.500.000.

\begin{tabular}{ccc}
\hline $\begin{array}{l}\text { Tabel 16. Penerimaan Pemilik } \\
\text { Penggarap }\end{array}$ & & \\
\hline $\begin{array}{c}\text { Penerimaan } \\
(\mathrm{Rp})\end{array}$ & Pemilik Lahan & Petani Penggarap \\
$1 / 3$ & $2 / 3$ \\
\hline 40.500 .000 & 13.500 .000 & 27.000 .000 \\
\hline
\end{tabular}

Sumber: Diolah Dari Data Primer, 2019

Tabel 16 menunjukkan bahwa pembagian hasil yang berlaku di Desa Wolaang, untuk pemilik lahan mendapat $1 / 3$ dari total penerimaan yaitu Rp.13.500.000 dan petani penggarap mendapat 2/3 dari total penerimaan yaitu Rp.27.000.000. Dapat dilihat bahwa penerimaan terbesar pada petani penggarap karena petani penggarap yang menanggung semua biaya produksi. 


\section{Pendapatan Usahatani Padi Sawah}

Pendapatan Usahatani merupakan selisih antara total penerimaan dengan total biaya. Pendapatan usahatani padi sawah di Desa Wolaang dapat dilihat pada tabel 17.

\begin{tabular}{lc}
\hline $\begin{array}{l}\text { Tabel 17. Pendapatan Usahatani Padi Sawah Per Musim } \\
\text { Tanam }\end{array}$ \\
\hline \multicolumn{1}{c}{ Uraian } & Nilai \\
& Rp) \\
\hline Penerimaan & 40.500 .000 \\
Pemilik Lahan & 13.500 .000 \\
Pajak & 37.500 \\
Pendapatan Pemilik Lahan & $\mathbf{1 3 . 4 6 2 . 5 0 0}$ \\
Petani Penggarap & 27.000 .000 \\
Biaya Produksi & 17.059 .135 \\
Pendapatan Petani Penggarap & $\mathbf{9 . 9 4 0 . 8 6 5}$ \\
\hline Sumber: Diolah Dari Data Primer, 2019 &
\end{tabular}

Tabel 17 menunjukkan bahwa penerimaan yang diterima pemilik lahan sebesar Rp. 13.500.000, karena pajak di tanggung oleh pemilik lahan maka pendapatan yang diterima pemilik lahan sebesar Rp.13.462.500. Untuk petani penggarap penerimaan yang diterima sebesar Rp.27.000.000, karena semua biaya produksi di tanggung semua oleh petani penggarap maka pendapatan yang diterima sebesar Rp.9.940.865. Hal terlihat jelas bahwa pendapatan yang diterima petani penggarap lebih kecil karena harus menanggung semua biaya produksi. Tetapi jika produksi menurun resiko di tanggung bersama antara pemilik lahan dan petani penggarap.

\section{KESIMPULAN DAN SARAN}

\section{Kesimpulan}

Hasil penelitian menunjukkan bahwa sistem bagi hasil yang berlaku di Desa Wolaang untuk pemilik lahan mendapat Rp.13.462.500 per musim tanam dan petani penggarap mendapat Rp.9.940.865 per musim tanam. Hal ini terlihat jelas bahwa pendapatan yang diterima petani penggarap lebih kecil dari pendapatan yang diterima oleh pemilik lahan.

\section{Saran}

Sebaiknya pemilik lahan seharusnya melakukan perubahan pola bagi hasil yang selama ini diterapkan dengan mempertimbangkan kontribusi biaya yang dikorbankan oleh petani penggarap.

\section{DAFTAR PUSTAKA}

Boediono. 2016. Ekonomi Mikro:Edisi Kedua,Cetakan Ketiga puluh satu. BPFE. Yogyakarta.

Daniel, M. 2001. Pengantar Ekonomi Pertanian. Medan: Bumi Aksara.

Rahardjo. 2004. Pengantar Sosiologi Pedesaan dan Pertanian. Yogyakarta: Gadjah Mada University - Press.

Sukirno 2006. Ekonomi Pembangunan Proses Masalah dan Dasar Kebijakan. Jakarta

Suratiyah. 2015. Ilmu Usahatani. Penebar Swadaya. Jakarta. 